\title{
Infantile hypertrophic pyloric stenosis (IHPS): it can take away your breath, alertness, wee and poo
}

\author{
Ramnik V Patel, ${ }^{1}$ Rebecca Wockenforth, ${ }^{2}$ Irene Milliken, ${ }^{2}$ David Marshall ${ }^{2}$
}

${ }^{1}$ Department of Paediatric Urology, University College London Hospitals NHS Foundation Trust, London, UK ${ }^{2}$ Department of Paediatric Surgery, Royal Belfast Hospital for Sick Children, Belfast, UK

\section{Correspondence to}

Ramnik V Patel,

ramnik@doctors.org.uk

\section{DESCRIPTION}

A 5-week old full-term previously healthy first-born male infant presented with apnoea, desaturations, increasing lethargy, anuria for 1 day and constipation for 5 days. This was on a background of persistent projectile non-bilious vomiting for 10 days, during which he had been given Carobel for presumed gastritis and gastro-oesophageal reflux. Father's cousin had pyloric stenosis. He was lethargic, pale and dehydrated with $14 \%$ weight loss. Heart rate was 130/ min, shallow respirations of $28 / \mathrm{min}$, intermittent desaturations to $70-80 \%$. He had epigastric fullness with visible peristalsis. He was started on $36 \%$ oxygen, given two boluses of normal saline. Urine dipstick after resuscitation showed $\mathrm{pH} 7.0$, venous blood gas showed $\mathrm{pH} 7.53, \mathrm{PCO}_{2}$ 9.2, $\mathrm{PO}_{2}$ 3.21, $\mathrm{HCO}_{3} 55$ and BE 27.8. ECG showed flat T-waves and ST-segment depression. Babygram ruled out pulmonary aspiration and showed a dilated stomach with paucity of distal gas. Ultrasound scan confirmed infantile hypertrophic pyloric stenosis (IHPS) (figure 1). He was intubated, ventilated and transferred to paediatric intensive care unit. After $72 \mathrm{~h}$ of biochemical correction, he underwent supraumbilical pyloromyotomy uneventfully.

IHPS is a common condition and the severity and duration of symptoms enhance loss of fluid, electrolytes and cause severe acid-base imbalance. This leads to dehydration with oliguria and anuria, hypokalaemia, hypochloraemia, severely metabolic alkalosis with compensatory respiratory acidosis. The mortality associated with IHPS was as high as $14.4 \%$ in 1935 , but improved to $0.5 \%$ in the late 1960 s, where it has held eversince. ${ }^{1}$ Only rarely now is apnoea and paradoxical aciduria seen in patients with pyloric stenosis. ${ }^{23}$

\section{(1) \\ CrossMark}

To cite: Patel RV, Wockenforth R, Milliken I, et al. BMJ Case Rep Published online: [please include Day Month Year] doi:10.1136/bcr-2013201435
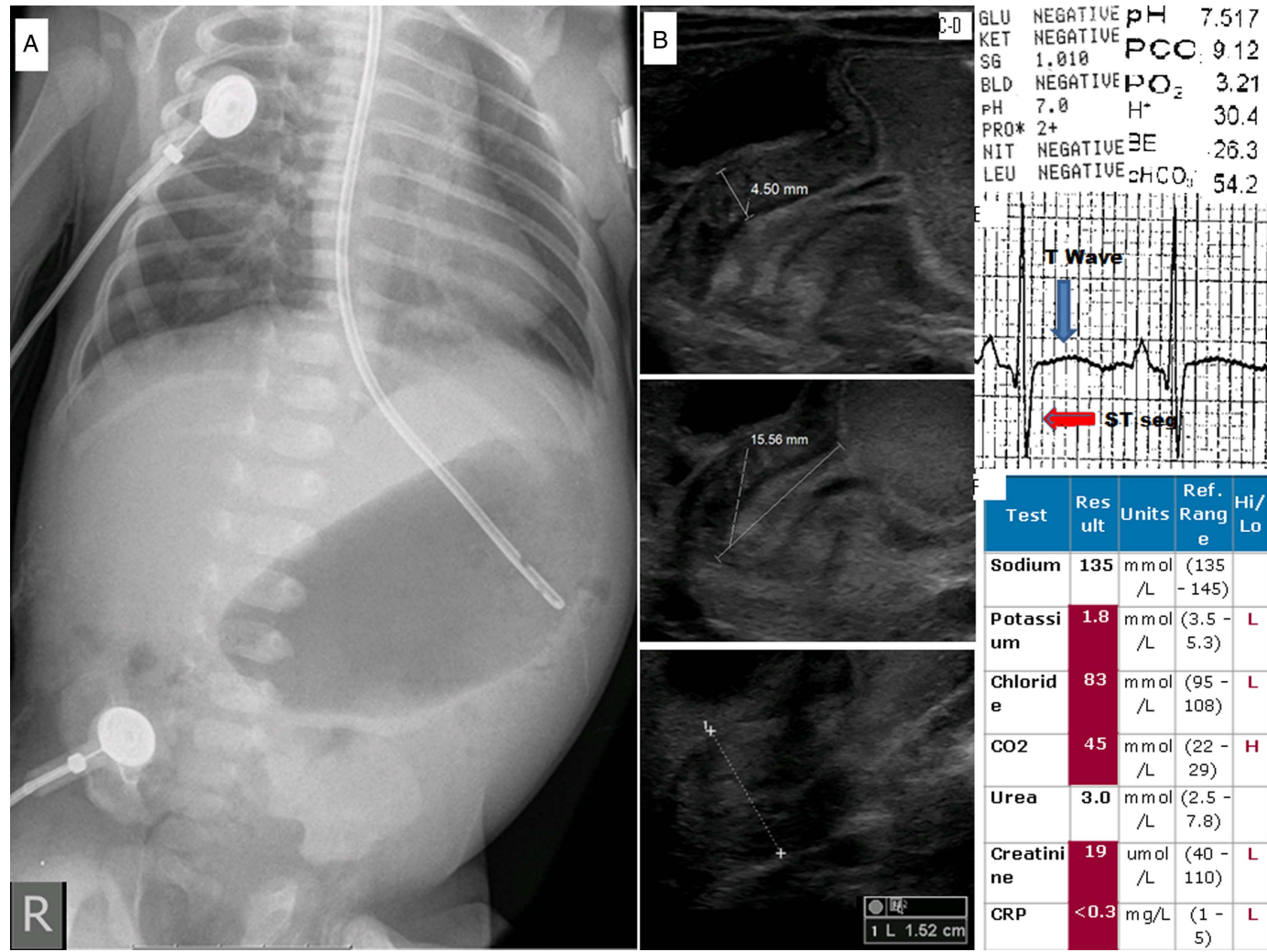

Figure 1 (A) Babygram, (B) abdominal ultrasound, (C) urinalysis, (D) capillary blood gas, (E) ECG and (F) serum electrolytes showing typical changes of advanced infantile hypertrophic pyloric stenosis (IHPS). 


\section{Learning points}

- Gastrointestinal and plasma compensation: Carobel thickens gastric contents, converting partial obstruction into complete one and prevents gastrointestinal compensation. Water gets absorbed from the colon producing constipation in addition to complete gastric outlet obstruction. Oral rehydration fluid helps restore balance and reduces vomiting as there are no milk curds to block the lumen.

- Renal compensation: The kidney compensates for this shift in fluid, electrolytes and acid/base imbalance by increasing the reabsorption of water, producing oliguria, preserves sodium and allows potassium to be excreted, responds to the alkalosis by decreasing bicarbonate reabsorption, producing alkaline urine in an attempt to decrease the serum bicarbonate level. Later on, when potassium level falls to dangerously low levels, it starts excreting hydrogen ions for potassium preservation and paradoxical aciduria is an advanced renal compensation to preserve life.

- Respiratory compensation: It promotes hypoventilation similar to that of hyperventilation in metabolic acidosis and an increased partial pressure of carbon dioxide and compensatory respiratory acidosis. The resultant hypoxia as a result of hypoventilation prevents its progression to overt respiratory failure. However, hypoventilation can in turn lead to atelectasis and hypoxaemia and apnoea is considered secondary to metabolic alkalosis associated with IHPS which is rare. The management should include continuous cardiorespiratory monitoring, pulse oximetry, oxygen, contingency plans for emergent airway stabilisation and management. Admission to general paediatric units and infant transport with personnel unprepared for managing the infant airway is ill-advised and may prove catastrophic.
Acknowledgements The authors are grateful to the paediatric accident and emergency and paediatric intensive care unit teams of the referring hospital and our hospital transport and paediatric intensive care unit teams for stabilisation and transfer safely and effectively.

Contributors All the authors have made substantial contributions to the conception and design of this manuscript, search of literature, the acquisition, analysis and interpretation of the data, to drafting the article or revising it critically for important intellectual content and to the final approval of the version to be published.

Competing interests None.

Patient consent Obtained.

Provenance and peer review Not commissioned; externally peer reviewed.

\section{REFERENCES}

1 Tigges CR, Bigham MT. Hypertrophic pyloric stenosis: it can take your breath away. Air Med J 2012;31:45-8.

2 Pappano D. Alkalosis-induced respiratory depression from infantile hypertrophic pyloric stenosis. Pediatr Emerg Care 2011;27:124.

3 McCauley M, Gunawardane M, Cowan MJ. Severe metabolic alkalosis due to pyloric obstruction: case presentation, evaluation, and management. Am J Med Sci 2006;332:346-50.

Copyright 2013 BMJ Publishing Group. All rights reserved. For permission to reuse any of this content visit http://group.bmj.com/group/rights-licensing/permissions.

BMJ Case Report Fellows may re-use this article for personal use and teaching without any further permission.

Become a Fellow of BMJ Case Reports today and you can:

- Submit as many cases as you like

- Enjoy fast sympathetic peer review and rapid publication of accepted articles

- Access all the published articles

- Re-use any of the published material for personal use and teaching without further permission

For information on Institutional Fellowships contact consortiasales@bmjgroup.com

Visit casereports.bmj.com for more articles like this and to become a Fellow 